\title{
Relevance of Knowledge Acquisition For Teaching and Learning as a Panacea for Growth of Business Education Programme
}

\author{
Dr. Pac Ordu \\ School of Business Education, Federal College of Education (Tech) \\ Omoku, Rivers State, Nigeria
}

\section{Doi:10.5901/jesr.2013.v3n7p721}

\section{Abstract}

Investment in education has been a topical issue in educational literatures, but the most disturbing aspect has been the type of education to channel investments. This paper aimed at presenting types of education that could be relevant to the development of business education programme. It also discussed the levels at which investments is actually needed for education to contribute effectively to teaching and learning in business education. The paper further highlighted the need for higher education programme of universities for business educators to contribute significantly to developing the programme. The paper concluded that the possession of business education degrees by her lecturers is the only way that business education can grow. It therefore recommended employment of persons with higher degrees in business education as a necessary step to developing the programme

\section{Introduction}

Research evidence has shown that investments in education is a what while project. This may account for one reason why some individuals exert lots of efforts to ensure that they are properly educated. It also accounts for the reason why nations expend much of their budgets on educational development. To the individuals, many reasons may account for their desire to be educated. Even in the context of the individual's desire to be educated, the type of education occupies his search for occupational area during his life time. When an individual has chosen his occupational area, he is ready to spend and put in more years of schooling since he beliefs that more years in school means better job. There are individuals who also feel that more years of schooling may mean a source of social mobility. These individuals, having become more educated, are sure that they have become more literate, more numerate and would have better work habits. Furthermore, they also belief that educated individual is easier to train and retrain, and also finds it easier to learn more complex tasks through creation of awareness of time and dependability at work performance.

For the nation state, the government works hard to investing more and more in education since by so doing, the average productivity would be improved. The nation also beliefs that raising standard of educated individuals will also translate to raising the quality of jobs in the economy and thereby raising standard of living. This rise in the quality of jobs of individuals and standard of living of citizens imports an increase in economic growth. This means that an educated workforce translates to an improved labour force which also has an increased capacity to produce improved goods and services.

From these, it is understood that a shortage of educated personnel in specific fields limits growth in that occupation. In business education programme, how relevant to growth are some types of education found within the programme may be the question for research work. Business education is a growing programme but there is need to determine the level at which teaching and learning of certain courses contribute to the growth of the programme. This may also be extended to finding out at what levels of education some qualifications make contributions to the growth of business education programme.

\section{Literature review}

According to Macdonald (2004), the countries that in 1980 had a higher level of the right type of education had a greater opportunity 20 years later, to reach a higher level of development. This means that those who saw and invested rightly in education earlier have the propensity to continuously grow and develop than those who saw but did not invest rightly. The right sort of education may infer education in the areas of needs of a particular occupation and the nation at a given period. This means that while learning in a recognized programme is encouraged, teaching in such programme must be 
made adequate by the provision of relevant materials and human resources. The right sort of human resources must refer to the teaching staff with the right educational certificates and in the right qualities to teach learners in that same programme. Dessus (2001) explained that growth can be interpreted as an expression of technological progress as well as the efficiency with which capital and labour are utilized. This opinion is apt in business education programme where capital and labout appear to be at par in the face of innovative changes. Nwosu (2009) informed that it is only business education programme that you can find holders of all sorts of unclassified degree certificates as lecturers. In this regards, growth as an expression of technological progress would be hampered since those lecturers without business education qualifications cannot interpret current technologies in the programme. In such a situation, their presence is nothing other than hampering technological growth of the programme.

Again, Osuala (2004) explained that there are marked differences between a business educator and a business studies teacher. To Osuala, a business educator is one whose training in business education programme cuts across first degree, master and doctoral, and is in the business of teaching students in any form prescribed by the national association. On the other hand, he explained that those teaching in business education programme without recognizable degree qualifications in business education are business studies teachers. Accordingly, these lecturers are grasshoppers and interlopers who found business education as a progamme to hopper since there was no place for them to secure employment. For such persons to remain and grow in business education, they must first undergo the refresher courses of the programme at the post graduate levels to enable them acquire the basic knowledge required by the programme for her teachers. Secondly, with the certification from the refresher courses, they can be admitted to undergo master degree programme or doctoral degree programme as the case may be, of business education in the universities some of which are available in Nigeria. This may further imply that to function effectively and contribute to the growth in teaching and learning of business education, the lecturer must possess the prescribed university business education degree certificates. This means that such lecturers would be more literate and numerical in business education programme, learn more things and easier to retrain in business education technological changes. Ordu (2012) explained that lecturers of business education background have better work habits with regards to awareness of time, relationship with technology of the programme, research supervision, teaching methodologies, etc.

This argument supports the opinion of Lodde (2000) that countries with higher levels of economic growth have labour forces with higher levels of formal schooling. He further advised that a developing programme has a better chance of catching up with more advanced technologies when such a programme has a stock of labour with necessary skills to develop new technologies. Business education programme in this regards, must have need to stock only those with the types of university degree that are indigenous to develop their necessary technologies.

Table 1: Preferred types of education in business education

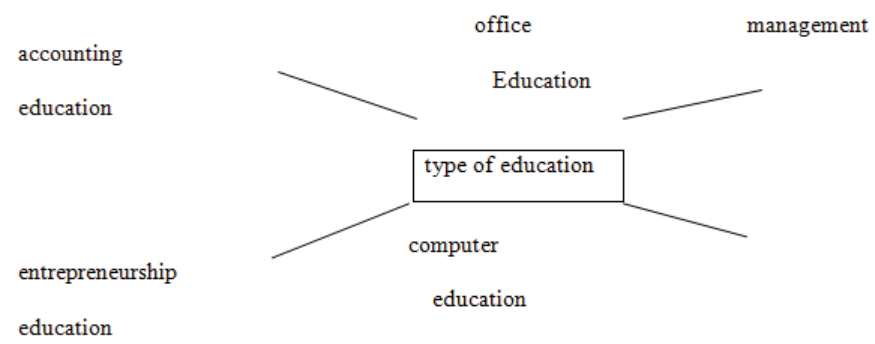

Source: Author's field work 2012

\section{Purpose of the study}

The major purpose of this study was to find out the type of education that contribute effectively to teaching and learning in business education programme. Specifically, the study sought to determine:

1. the types of education contribute effectively to teaching and learning in the growth of business education programme.

2. the level of education at which teaching and learning of entrepreneurship education contribute to growth in business education programme. 
3. the level of education at which teaching and learning of computer education contribute to growth in business education programme.

4. the level of education at which teaching and learning of accounting education contribute to growth in business education programme.

5. the level of education at which teaching and learning of office management education contribute to growth in business education programme.

6. the classification of acquired degrees at the university education that contribute effectively to the growth of business education programme.

\section{Research questions}

1. How do these types of education contribute effectively to teaching and learning in the growth of business education programme?

2. At which of these levels of education does teaching and learning of entrepreneurship education contribute effectively to the growth of business education programme?

3. At which of these levels of education does teaching and learning of computer education contribute effectively to the growth of business education programme?

4. At which of these levels of education does teaching and learning of accounting education contribute effectively to the growth of business education programme?

5. At which of these levels of education does teaching and learning of office management education contribute effectively to the growth of business education programme?

6. At the university level, what classification of acquired degrees contribute effectively in teaching and learning to growth of business education programme?

\section{Methodology}

The study was carried out in Rivers State and only business educators were used. A survey design was used for this study because according to Osuala (2004), survey is ideal for studies that focus on people's opinion and their attitudes about a particular matter. The population was made up of 60 business educators selected from Federal College of Education (Tech) Omoku (20), Rivers State University of Science and Technology (5), Rivers State University of Education (20), and Rivers College of Arts and Science (15). Due to its manageable size and spread, the entire population was used for the study. The instrument used for data collection was a structured questionnaire which contained six sections.

Section one contained 10 question-items while sections two contained six question-items each. The instrument was validated in sections by the same experts in business education programme and their inputs at each stage of validation were reflected to strengthen the instrument. Section one was administered to respondents and retrieved the same day through the help of appointed research assistants in business education units of the institutions. This section was analysed and four types of education that had mean scores of 2.50 and above were selected and compiled again to give, in order of ratings, sections two-five. This set containing research questions two to five was administered one week later to the same respondents by the same research assistants and retrieved the same day. The data were analysed to compile section six. This section was equally administered by the same research assistants one week later to the same group of respondents and retrieved the same day. At each stage of the study, reliability of the study was checked using Cronbach's alpha co-efficient which gave 0.77 . The results of the study was analysed using mean statistic. At each stage, the result was said to be acceptable if the mean rating was 2.50 and above, and was said to be unacceptable if the mean rating was less than 2.50 .

\section{Data presentation and analysis}

\subsection{Research question one}

How do these types of education contribute effectively to teaching and learning in the growth of business education programme? 
Table 1: Types of education on effective contribution to teaching and learning

\begin{tabular}{|c|l|c|c|c|c|c|c|}
\hline & Type & VHE & VE & LE & VLE & sum & $X$ \\
\hline 1 & General education & 9 & 11 & 29 & 11 & 60 & 2.30 \\
\hline 2 & Office management education & 20 & 18 & 12 & 10 & 60 & 2.62 \\
\hline 3 & Computer education & 23 & 19 & 10 & 5 & 60 & 3.03 \\
\hline 4 & Teaching practice education & 17 & 16 & 08 & 16 & 60 & 2.47 \\
\hline 5 & Entrepreneurship education & 25 & 20 & 11 & 4 & 60 & 3.23 \\
\hline 6 & Economic education & 05 & 10 & 13 & 32 & 60 & 1.82 \\
\hline 7 & Management education & 14 & 11 & 21 & 14 & 60 & 2.38 \\
\hline 8 & Marketing education & 13 & 54 & 16 & 15 & 60 & 2.48 \\
\hline 9 & Business administration & 11 & 16 & 20 & 13 & 60 & 2.42 \\
\hline 10 & Accounting education & 21 & 14 & 12 & 13 & 60 & 2.72 \\
\hline
\end{tabular}

The analysis in Table 1 shows that office management education, computer education, entrepreneurship education and accounting education had the mean of 2.50 and above, and therefore accepted for the study. The rest items had less than 2.50 and are therefore not accepted for the study. The items accepted for the study are rated in this order entrepreneurship education (3.23), computer education (3.03), accounting education (2.72), and office management education (2.62).

\subsection{Research question two}

At which of these levels of education could a teacher be accepted to teach entrepreneurship education in order to contribute effectively to the growth of business education programme?

Table 2: Levels of education preferred for the teaching of entrepreneurship

\begin{tabular}{|c|l|c|c|c|c|c|c|}
\hline & Level & VHE & HE & LE & VLE & Sum & X \\
\hline 1 & Primary education & 13 & 14 & 14 & 19 & 60 & 2.35 \\
\hline 2 & Formal education at secondary level & 10 & 15 & 17 & 18 & 60 & 2.28 \\
\hline 3 & Informal education at post secondary level & 15 & 12 & 16 & 17 & 60 & 2.42 \\
\hline 4 & Polytechnic level & 15 & 13 & 11 & 21 & 60 & 2.37 \\
\hline 5 & College of education level & 17 & 13 & 11 & 19 & 10 & 2.47 \\
\hline 6 & University level & 16 & 13 & 17 & 14 & 60 & 2.52 \\
\hline
\end{tabular}

Analysis of data on Table 2 show a shift of opinion to university level which scores a mean of 2.52 as against the cut-off point of 2.50. This was considered adequate for the study and was therefore accepted for further investigations. The rest five items did not meet up the cutoff point of 2.50 and therefore not accepted for the study. This implies that teaching of entrepreneurship education in business education programme was better handled by university trained lecturer in business education.

\subsection{Research question three}

At which of these levels of education could a teacher be accepted to teach computer education in order to contribute effectively to the growth of business education programme?

Table 3: Levels of education preferred for the teaching of computer education

\begin{tabular}{|c|l|c|c|c|c|c|c|}
\hline & Level & VHE & HE & LE & VLE & & \\
\hline 1 & Primary education & 12 & 17 & 12 & 19 & 60 & 2.43 \\
\hline 2 & Formal education at secondary level & 10 & 20 & 14 & 16 & 60 & 2.40 \\
\hline 3 & Informal education at post secondary level & 09 & 12 & 17 & 22 & 60 & 2.13 \\
\hline 4 & Polytechnic level & 14 & 17 & 13 & 16 & 60 & 2.45 \\
\hline 5 & College of education level & 14 & 15 & 17 & 14 & 60 & 2.47 \\
\hline 6 & University level & 19 & 13 & 15 & 13 & 60 & 2.63 \\
\hline
\end{tabular}


The analysis in Table 3 shows that university level teaching and learning was rated 2.63 compared to the cut-off point of 2.50. The implication of this is that the teaching of computer education to learners should be handled by somebody who possesses university degree. This shows that the university trained certificated personnel has a higher contributory effect on business education programme than teachers from other levels. This was accepted for the study while others that did not meet the cut-off point were not accepted for the study.

\subsection{Research question four}

At which of these levels of education could a teacher be accepted to teach accounting education in other to contribute effectively to the growth of business education programme?

Table 4: Levels of education preferred for the teaching of accounting education

\begin{tabular}{|c|l|c|c|c|c|c|c|}
\hline & Level & VHE & HE & LE & VLE & & \\
\hline 1 & Primary education & 11 & 15 & 17 & 17 & 60 & 2.33 \\
\hline 2 & Formal education at secondary level & 15 & 12 & 18 & 18 & 60 & 2.29 \\
\hline 3 & Informal education at post secondary level & 12 & 16 & 14 & 18 & 60 & 2.37 \\
\hline 4 & Polytechnic level & 15 & 12 & 18 & 15 & 60 & 2.45 \\
\hline 5 & College of education level & 14 & 15 & 17 & 14 & 60 & 2.48 \\
\hline 6 & University level & 17 & 14 & 16 & 13 & 60 & 2.58 \\
\hline
\end{tabular}

Data analysis on Table 4 shows university level education with a mean of 2.58 as against the rest five levels with means below the cut-off point of 2.50. This means that the teaching of accounting education is preferred if a university degree holder is involved. The university trained lecturer has an effective contribution to the growth of business education programme than teachers with qualifications outside university degree. The university level education was accepted for the study while the rest levels were not accepted.

\subsection{Research question five}

At which of these levels of education could a teacher be accepted to teach office management education contribute effectively to the growth of business education programme?

Table 5: Levels of education preferred for the teaching of office management education

\begin{tabular}{|c|l|c|c|c|c|c|c|}
\hline & Level & VHE & HE & LE & VLE & & \\
\hline 1 & Primary education & 11 & 13 & 19 & 17 & 60 & 2.30 \\
\hline 2 & Formal education at secondary level & 14 & 10 & 17 & 19 & 60 & 2.32 \\
\hline 3 & Informal education at post secondary level & 14 & 13 & 17 & 16 & 60 & 2.42 \\
\hline 4 & Polytechnic level & 13 & 14 & 14 & 19 & 60 & 2.35 \\
\hline 5 & College of education level & 14 & 15 & 17 & 18 & 60 & 2.48 \\
\hline 6 & University level & 16 & 17 & 16 & 11 & 60 & 2.63 \\
\hline
\end{tabular}

The analysis of data on Table 5 indicate that university level education has a mean of 2.63 as against the cut-off point of 2.50. This implies that teaching and learning of office management education should be handled by a lecturer who has trained at a university. It further means that the university degree teacher contributes more than lecturers trained from other levels to the growth of business education programme.

\subsection{Research question six}

At the university level, what classification of degree holders contribute effectively to growth of business education programme? 
Table 6: Classifications of preferred university teaching degrees

\begin{tabular}{|c|c|c|c|c|c|c|c|}
\hline & Classification & VHE & HE & LE & VLE & & \\
\hline 1 & B.Sc & 09 & 13 & 16 & 22 & 60 & 2.15 \\
\hline 2 & B.Ed & 17 & 13 & 16 & 14 & 60 & 2.55 \\
\hline 3 & PGDE & 14 & 13 & 16 & 17 & 60 & 2.40 \\
\hline 4 & M.Sc & 10 & 13 & 18 & 19 & 60 & 2.20 \\
\hline 5 & M.Ed & 16. & 16 & 19 & 11 & 60 & 2.68 \\
\hline 6 & Ph.D & 16 & 20 & 14 & 10 & 60 & 2.70 \\
\hline
\end{tabular}

Analysis of data on Table 6 reveal a mean score of 2.55 for B.Ed., 2.68 for M.Ed., and 2.70 for Ph.D compared to the cutoff point of 2.50. B.Sc has a mean of 2.15, M.Sc has a mean of 2.20, while PGDE has a mean of 2.40, and therefore below the cut-off point of 2.50. The lecturers with the degrees that scored the mean above 2.50 were accepted for the study and were preferred as ideal personnel to teach in business education programme. This implies that the acquisition of these degrees in business education make effective contributions in teaching and learning of business education programme than other degrees.

\section{Discussions of findings}

The study examined the types of education that contribute effectively to the growth and development of business education programme in Nigeria. It was revealed that the following types of education have the capacity to impact on the growth of business education programme: entrepreneurship education, computer education, accounting education and office management education. By examining these types of education, the study also looked at the levels and classification of degree certificates for teaching that are highly contributory to the growth of the programme. The analysis of results in Table 1 reveals that not all types of teaching certifications found in the teaching group are useful in teaching and learning in business education. This is in line with the opinion of Igbokwe (2010) who explained that if we must ensure efficiency and effectiveness in the programme, then we must consider the question of who should administer the programme in the interest of students. This is necessary to determine in view of the fact that the teacher, according to Ndinachi (1987) bears the burden of explaining the curriculum foundation to learners.

Furthermore, from the results in Tables 2-5, the study examined various levels of education at which greater impact flows from the teacher who is impacting knowledge to learners in the course of teaching and learning in business education programme. This was necessary to determine the level of education at which the teaching and learning required of various courses as listed above could be maximized. These results corroborate the view of Nwosu (2003) that the primary purpose of business education is that of preparing the recipient for gainful employment in business office occupations. Such gainful office employment, by the objectives of business education could be paid or self employment. From the listing, it was noted that the findings support Oduma (2010) that the emphasis of business education is on exposure to and acquisition of knowledge and competencies relevant and adequate for employment in specific business occupations.

Table 6 reveals the classification of degree certificates that are necessary for teaching appointments in business education programmes. The analysis shows that respondents preferred a Ph.D in business education as a necessity, followed closely by the possession of Masters degree (2.68) in business education. The least preferred is the possession of a bachelorette degree in business education that recorded the mean of 2.55. The rest degrees did not meet up the cut-off point of 2.50 which is an indication that they do not contribute significantly to the growth and development of business education programme. This is in line with Ikpo (2010) who averred that qualitative and relevance of degrees are basic needs of teaching in any vocational educational programme without which the programme would lose its focus of producing qualitative and skilled graduates.

\section{Conclusions}

From the results of findings and discussions, it is apt to conclude that the growth of business education depends largely on the availability of qualitative teaching staff with relevant degrees in the programme. This is shown from the agreement 
of respondents that the present society requires business education to lay emphasis on teaching and learning in productive and innovative courses. Igbokwe (2010) and Okwoli \& Anyakwu (2010) emphasized that training future business teachers without adequately preparing them to be creative in line with the innovative office environment will make them inefficient, ineffective and dysfunctional.

\section{Recommendations}

Based on the discussions and conclusions, the following recommendations were made:

1. Curriculum planners in business education should look inwards and involve productive courses in business education teaching and learning programme

2. Emphasis should be laid on the production and employment of qualitative degree holders to teach in business education departments.

3. Those teaching in business education department without relevant teaching qualifications should be encouraged to upgrade their present qualification by acquiring requisite business education degrees.

\section{References}

Dessus, S. (2001). Human capital and growth: the recovered role of educational system: Middle East and North Africa Working Paper 22, World Bank, Washington, DC.

Igbokwe, S. A. (2010). Issues in administration and supervision of business and vocational education programme in Nigeria. Journal of Business and Vocational Education, 1 (1): 1-8.

Ikpo, U. S. (2010). Transiting from vocational education to work, procedures based on qualifications in the $21^{\text {st }}$ century. Journal of Research and Production, 16 (12):177-184.

Lodde, S. (2000). Education and growth: Some disaggregate evidence from the Italian region. Sandina: Centre for North South Economic Research Working Paper Series CREMoS 199911.

Macdonald, C. (2004). Preparing for 21st century opportunities. New York: Macmillan Publishers.

Ndinachi, G. I. (1987). Business teacher education: Which home? Business Education Journal, 11 (1):21-24.

Nwosu, B. O. (2003). Business education in the 21st century: The challenges of technology. Business Education Book of Readings, 1 (2): 8-27.

Nwosu, B. O. (2009). Job creation through business education and the challenges of national economic empowerment and development strategy (NEEDS). Business Education Book of Readings, 1 (7): 18-27.

Oduma, C. A. (2010). Survey of employers' perception of the professional business competencies needed by business education graduates for gainful employment in organizations. Journal of Business and Vocational Education, 1 (1): 25-37 .

Okwoli, A. A. \& Anyakwu, M. A. (2010). Entrepreneurship development for practicing accountants, Jos: G-tel Press.

Ordu, P. (2012). Introduction to vocational education. Omoku: Jef Computers Services.

Osuala, E. C. (2004). Principles and practice of small business management in Nigeria. Enugu: Cheston Agency Ltd. 